\title{
A ética da compaixão como arma de combate ao pior dos mundos possíveis
}

\author{
Gilmara Coutinho Pereira \\ Mestranda PPGFIL - UFPB
}

RESUMO: O presente artigo se propõe mostrar como podemos escapar dos sofrimentos oriundos da vontade, negando-a. Tanto a afirmação quanto a negação da vontade consiste no conhecimento de si. Quando o homem toma consciência de si enquanto fenômeno, ele se torna claro e distinto a si mesmo, livre de qualquer ilusão. Assim ele dirá que aceita a tensão entre o querer o que não tem e o entediar-se com o que possui, ou, do contrário, negará a Vontade, suprimindo o querer. Uma das vias de negação da vontade é a compaixão, que se dá quando tomamos consciência do que somos: uma unidade; e, passamos a perceber o outro como parte nossa. Passamos a visar não o bem particular, mola impulsora do egoísmo, mas o bem-estar coletivo, que restaura a união do homem com os demais seres.

PALAVRAS-CHAVE: Vontade, Negação, Compaixão.

ABSTRACT: The purpose of this paper is to show how we can escape of the sufferings caused by Will in a way that deny it. The affirmation or the negation of the Will consists in the knowledge of itself. When the man is aware of consciousness itself as a phenomenon, he has a clear and distinct idea of himself and he is exempt of any illusion. Thus he accepts the tension between the desire of what he does not have and the boredom of what he owns or on the opposite, he will deny the Will and he will abolish the desire. A possible way to deny the Will is the compassion, and it is only possible when one is aware of what is: a unit. Then he begins to perceive the other as a part that belongs to him. Instead to aim the private wishes, what conceives the egoism, he searches the collective well-being, that reintegrate the union of the man with the others beings.

KEY-WORDS: Will, Negation, Compassion.

\section{O pior dos mundos possíveis: Uma introdução}

Ao sondar o enigma do mundo, Schopenhauer vê que o que há por trás de tudo, a essência do universo, outra coisa não é senão sofrimento, gerado pela oscilação entre dor e tédio. Segundo ele, vivemos no pior dos mundos possíveis e, nosso desejo deve ser apenas um: de que esse mundo, tal como ele existe, nunca tivesse existido. A humanidade serve de joguete ao querer da vontade saindo sempre como perdedora nessa disputa dela consigo mesma. O sofrimento gerado pela vontade não cessa, é eterno. Não obstante, nos iludimos às vezes em acreditar na felicidade. Não há felicidade duradoura A satisfação não passa de um ponto de partida para um novo esforço. Tanto a causa de nosso sofrimento quanto a causa de nossa alegria reside em pensamentos abstratos, não na realidade dos acontecimentos. 
A negação da vontade pode se dá através da arte, quando nos consolamos dos tormentos impostos pela tensão da Vontade onipresente: no momento que se fundem homem e objeto artístico, ambos deixam de existir separados e passam a ser uma mesma coisa. Através da compaixão, que se dá quando tomamos consciência do que somos: uma unidade; e, passamos a perceber o outro como parte nossa. Passamos a visar não o bem particular, mola impulsora do egoísmo, mas o bem-estar coletivo, que restaura a união do homem com os demais seres. Ou ainda, através da ascese, na negação do próprio corpo, o encontro com o Nada.

Segundo Schopenhauer, a esperteza permite ao homem dissimular seus sentimentos mais baixos, como a inveja, a crueldade. Não é possível medir exatamente o grau de compaixão ou de maldade presente nos indivíduos, pois a diferença existente entre os homens é "inavaliavelmente grande" inatas, que medir com precisão o caráter bom ou mau de alguém constitui-se um verdadeiro mistério. De forma que poderia nos assustar um conhecimento mais íntimo do nosso ser ou do ser do outro. Schopenhauer atribui a isso o surgimento da amizade entre os homens e os quadrúpedes, pois estes são mais transparentes e fiéis. O próprio Schopenhauer teve como melhor amigo, em boa parte de sua vida, um poodle que atendia por Atma (palavra que em sânscrito significa a alma do mundo):

[...] francamente, como se restabelecer da infinita dissimulação, falsidade e malícia dos homens, se não houvesse os cães, em cuja face honesta podemos mirar sem desconfiança? Nosso mundo civilizado não passa de uma imensa mascarada. Ali encontramos cavaleiros, padres, soldados, doutores, advogados, sacerdotes, filósofos, e o que não mais! Porém estes não são o que representam: são simples máscaras, sob as quais, via de regra, se situam especuladores financeiros (moneymakers). [...] Portanto, que mesmo o jovem já seja informado que nesta mascarada as maçãs são de cera, as flores de seda, os peixes de papelão, e que tudo, tudo é futilidade e brincadeira: e que, daqueles dois, vistos ali a negociar tão seriamente, um fornece somente mercadoria falsa, e outro paga com meras fichas ${ }^{2}$.

Aqui todo o pessimismo schopenhaueriano denunciando um mundo de falsidade, maya (ilusão), em que cada um interpreta um personagem sempre a fim de ludibriar o outro e, por vezes, a si mesmo. Aqui também a inclusão de outros seres, não só os humanos,

\footnotetext{
${ }^{1}$ SCHOPENHAUER, A. P/P, p. 194.
}

${ }^{2}$ SCHOPENHAUER, A. P/P, p. 195. 
numa abordagem ética da existência; o que dá um caráter diferenciado à ética schopenhaueriana frente às outras, que se ocupam apenas da dignidade humana, que coloca o homem num pedestal em relação aos outros seres da natureza. Todos os seres tem espaço na ética schopenhaueriana. Não fosse vivermos de maneira "domesticada", "mascarada", no dizer de Schopenhauer, enfim, civilizada, sabe-se lá que tipo de aberrações presenciaríamos da parte dos outros ou mesmo nossa! "Onde e quando a trava e a cadeia da ordem jurídica se rompem, e se instaura a anarquia, se revela o que se é"3.

Há duas formas de apreendermos nossa própria existência. A primeira diz respeito à "intuição empírica", apreendendo o fenômeno através do princípio de individuação; e a segunda se dá por um mergulho em si mesmo, este nos permite um contato com nossa essência, a coisa-em-si. Isto pode parecer estranho, dada a incognoscibilidade da coisa-em-si, mas aqui nos referimos, quando falamos de coisa-em-si, à Vontade e, esta é cognoscível através do mergulho do homem em si mesmo, ele, o corpo humano que é onde se dá o maior grau de objetivação da Vontade, não desconsiderando que a Vontade se faz presente em tudo o que há no mundo:

Pois a coisa-em-si, o querer viver está em todo ser, inclusive o mais ínfimo, totalmente e individido, tão perfeito como em todos que jamais existiram, existem, e existirão, tomados em conjunto. [...] E, na verdade, se todos os outros seres desaparecessem, neste um que sobrou existiria todo o ser em si do mundo, sem mácula e diminuição, rindo deste desaparecimento como de uma charlatanice ${ }^{4}$.

\section{Uma felicidade negativa}

O pessimismo de Schopenhauer não dá espaço para a espera por mundo melhor, como pensam os cristãos; uma esperança que, de certa forma, serve como um estímulo para suportar as dores deste mundo: não há um além mundo no qual receberemos uma recompensa por bom comportamento ou, uma punição às nossas maldades e nossas fraquezas. O bíblico "juízo final” é aqui e agora, dá-se neste mundo — o tribunal do mundo é o próprio mundo.

\footnotetext{
${ }^{3}$ SCHOPENHAUER, A. P/P, p. 195.

${ }^{4}$ SCHOPENHAUER, A. P/P, p. 202.
} 
O capítulo XII dos Parerga e Paralipomena, fala que toda nossa vida está voltada para o sofrimento e, que seria o maior contra-senso negar isto. Basta uma olhada na história e, veremos os grandes relatos de guerras, infortúnios, permeados por "entre-atos" de paz. $\mathrm{Na}$ filosofia de Schopenhauer, a dor tem caráter positivo, pois é, de fato, o que existe, a felicidade é negativa, pois é apenas um momento em que a dor cessa, ou se atinge um desejo; diga-se de passagem - a infelicidade é a regra. Nos aborrece mais um desconforto insignificante do que a fluidez da totalidade de nossos interesses. Notemos o quão felizes ficamos diante de uma conquista, comparado ao quão triste ficamos diante de um fracasso; a segunda experiência é sempre mais marcante. A ideia comum de que nos tornamos menos insatisfeitos com nossas dores quando encontramos alguém em situação pior que a nossa, é confirmada por Schopenhauer como "o consolo mais eficaz em toda infelicidade" 5. Travamos uma luta não só contra a necessidade e o tédio, mas também, contra os outros. Sofrimentos oriundos de uma Vontade cega, poderosa, inescrupulosa:

Parecemos carneiros a brincar sobre a relva, enquanto o açougueiro já está a escolher um ou outro com os olhos, pois em nossos bons tempos não sabemos que infelicidade justamente agora o destino nos prepara -, doença, perseguição, empobrecimento, mutilação, cegueira, loucura, morte, etc ${ }^{6}$.

O homem busca o mesmo que os demais animais: saúde, alimentação, proteção do frio e da umidade e satisfação sexual; contudo, no homem, quando estas necessidades básicas não são satisfeitas, o desastre é bem maior, bem como os ardis para consegui-los:

Isto se deve em primeiro lugar ao fato de nele tudo sofrer um poderoso acréscimo mediante o pensar no ausente e futuro, através do qual preocupação, temor, esperança, adquirem existência, após o que contudo atuam sobre ele com muito mais intensidade do que possível à realidade presente dos prazeres ou dos sofrimentos a que está restrito o animal. A este falta, com a reflexão, o condensador das alegrias e dos sofrimentos, que destarte não são passíveis de acumulação, como sucede no homem, por meio da memória e da previsão: no animal, o sofrimento do presente, mesmo retido vezes inumeráveis, sempre permanece apenas como da primeira vez, sem conseguir se adicionar. Daí a inegável despreocupação e tranqüilidade dos animais ${ }^{7}$.

\footnotetext{
${ }^{5}$ SCHOPENHAUER, A. P/P, p. 217.

${ }^{6}$ SCHOPENHAUER, A. P/P, p. 217.

${ }^{7}$ SCHOPENHAUER, A. P/P, p. 218.
} 
No entanto, diz Schopenhauer, que seria do homem não fosse ocupar seu tempo correndo atrás da satisfação de seus desejos ou tentando escapar do sofrimento?! É possível que ele, o homem, explodisse em sua petulância, é o que diz nosso filósofo. Num mundo idealmente perfeito - o melhor dos mundos possíveis — é provável que o homem desse um jeito de promover as desgraças que a natureza não lhe impôs, na tentativa de, assim, escapar ao tédio: "para uma tal espécie, como a humana, nenhum outro palco se presta, nenhuma outra existência"»

A morte é um acréscimo de dor e angústia conferido ao homem, pois, só ele espera pela morte, tem consciência de sua existência. Nascimento e morte são pólos da vida de todo fenômeno. Futuro e passado são abstrações do intelecto - o que existe deveras é apenas o presente. Não há, portanto, por que se lamentar com o que deixamos de viver ou com o que vivemos de ruim, quando a morte sobrevir. Como o indivíduo nada mais é que vontade de vida, todo o seu ser acaba por se insurgir contra a morte. A vida de nosso corpo é um morrer continuamente evitado. Todas as ações de nosso corpo (respiração, alimentação, repouso, aquecimento corpóreo, etc.) são defesas contra a morte. O homem que percebe essa luta como desnecessária, encontra no conhecimento de si uma arma para superar com indiferença o medo da morte. Mesmo porque, considerando que vivemos no pior dos mundos possíveis, a morte pode mesmo vir a ser pensada como um bálsamo: "Por que me inquietar com a perda desta individualidade, eu que trago em mim a possibilidade de individualidades sem conta?" 9 . “[...] a morte não atinge o ser vivo no próprio núcleo do seu ser, no seu querer-viver. A consciência individual, que desaparece, estava ligada ao fenômeno espácio-temporal do mundo da representação" ${ }^{10}$. O apego a vida surge do que há de mais profundo em nós, o querer: “é a parte imortal do nosso ser que faz a morte temível; e é a parte mortal que, na verdade, não a teme", ${ }^{11}$.

Ao contrário do homem, o animal irracional consegue desfrutar da serenidade da não preocupação com o futuro, vivem o presente:

O animal é o presente corporificado, a tranqüilidade visível de que assim se investe, muitas vezes envergonha nosso estado, frequentemente intranqüilo e insatisfeito à causa de pensamentos e preocupações. [...] $\mathrm{O}$

\footnotetext{
${ }^{8}$ SCHOPENHAUER, A. P/P, p. 217.

${ }^{9}$ SCHOPENHAUER, apud LEFRANC, J. Compreender Schopenhauer, p. 142.

${ }^{10}$ LEFRANC, J. Compreender Schopenhauer, p. 139.

${ }^{11}$ LEFRANC, J. Compreender Schopenhauer, p. 140.
} 
animal por sua vez permanece livre deste prazer antecipado, e também desta dedução posterior, gozando assim o presente e real por inteiro e sem alteração. E da mesma forma, os males oprimem este último somente com seu peso real e próprio, enquanto para nós o temor e a previsão [...] frequentemente o decuplicam ${ }^{12}$.

Talvez seja essa serenidade o que desperta a inveja e a crueldade de alguns homens que maltratam os animais, os enjaulando e chicoteando, dentre outras perversidades. A maldade é tão inata à natureza humana, que sua maior necessidade, que é o ato de procriação, resulta em dar continuidade à espécie, carregada de sofrimento — "o ato da geração forma o nó do mundo" ${ }^{13}$.

A necessidade sexual é ainda mais fundamental que a fome pelo fato de ligar cada indivíduo à espécie. Pela sexualidade o próprio querer-viver se afirma no indivíduo por intermédio da espécie, ou mais exatamente na espécie por intermédio do indivíduo e além da existência individual. 'Ele é em todo o mundo tacitamente suposto como necessário, e não é como os outros desejos (wünsche) questão de gosto e de humor: pois é ele o desejo que constitui o próprio ser do homem, 14 .

Por mais que dissimulem, o "instinto sexual" é matéria corrente no pensamento de todos os homens: "É no ato procriador que o querer-viver se manifesta do modo mais direto sem intervenção do conhecimento, ou seja, como coisa-em-si, distinta da volição consciente" 15. Diz Lefranc, citando os Suplementos de Schopenhauer: "O homem é um instinto sexual que toma corpo" ${ }^{16}$. Com isto, não queremos dizer que Schopenhauer desconsidera o valor e a existência da paixão que pode surgir entre as pessoas; os romances, muitas vezes extraídos de histórias reais, bem como cada homem ou mulher podem atestar sua existência. Contudo, a paixão se distingue do instinto sexual, segundo nosso filósofo, apenas quanto à "individualização da escolha amorosa": "a tragédia da paixão amorosa está na sua individualização, isto é, na exasperação do conflito do indivíduo e da espécie" ${ }^{17}$. A existência da humanidade futura depende dos instintos sexuais, bem como sua essência depende da "escolha" feita por cada um em vista de sua satisfação pessoal; pois, segundo Schopenhauer, do pai, herda-se o caráter e, da mãe, o intelecto. O homem, ao escolher uma

\footnotetext{
${ }^{12}$ SCHOPENHAUER, A. P/P, p. 220.

${ }^{13}$ SCHOPENHAUER, A. P/P, p. 230.

${ }^{14}$ LEFRANC, J. Compreender Schopenhauer, p. 133.

${ }^{15}$ LEFRANC, J. Compreender Schopenhauer p. 135.

${ }^{16}$ LEFRANC, J. Compreender Schopenhauer p. 134.

${ }^{17}$ LEFRANC, J. Compreender Schopenhauer p. 137.
} 
moça para desposar, leva em consideração se esta traz em si uma boa constituição física capaz de gerar uma criança saudável; assim como a mulher, ao escolher um homem para contrair matrimônio, verifica se este seria um bom provedor de alimento e tudo o mais que se faz necessário para o desenvolvimento de uma criança. O fim, portanto, não é outro senão a conservação da espécie: "Podemos dizer que o mundo como vontade é igualmente o mundo como Eros" 18 .

Se agissem de forma compassiva, considerando o caos que é viver, os homens logo optariam por não dar continuidade à humanidade, de modo que esta logo desapareceria: “o mundo constitui o inferno, e os homens formam em parte os atormentados, e noutra, os demônios" ${ }^{19}$. Para quem deseja uma outra perspectiva do mundo, menos pessimista e des-esperada, Schopenhauer sugere que procure uma igreja; lá encontrarão otimismo de sobra! Ainda assim, aproveita do antigo testamento a ideia do "pecado original" como justificativa para tanta miséria, visto que desde nosso nascimento já somos assolados por tantas desgraças. "Poder-se-ia pensar que o tratamento apropriado entre os homens, em lugar de Monsieur, Sir, etc., deveria ser companheiro de infortúnio, soci malorum, compagnon de misères, my fellow-sufferer" ${ }^{20}$, satiriza Schopenhauer.

A causa do sofrimento do mundo é o querer insaciável que, a cada satisfação, encontra um novo desejo; de modo à nunca estar plenamente satisfeito. E, quando se tem a impressão dessa plena satisfação, assalta-nos o tédio: "Nenhum sentimento revela mais diretamente do que o tédio o radical absurdo da existência humana: querer sem nada querer" ${ }^{21}$. Por isso, Schopenhauer considera a felicidade como algo negativo: se tudo o que há é sofrimento, apenas na ausência deste é que se dá a alegria, a felicidade que, por sua vez, não passa de uma visitante apressada — “o ser humano é uma necessidade que nenhum objeto satisfaz" 22 .

Em contraposição ao fundamento da ética, temos a potência antimoral do egoísmo (selbstsucht $=$ amor próprio). Embora não seja o egoísmo a única motivação antimoral, é a primeira que deve ser combatida pela motivação moral da compaixão (mitleid). Enquanto a máxima da compaixão é "ajude a todos, sempre", a do egoísmo é "não ajudes a ninguém,

\footnotetext{
${ }^{18}$ LEFRANC, J. Compreender Schopenhauer p. 136.

${ }^{19}$ SCHOPENHAUER, A. P/P, p. 223.

${ }^{20}$ SCHOPENHAUER, A. P/P, p. 225.

${ }^{21}$ LEFRANC, J. Compreender Schopenhauer, pp. 167-168.

${ }^{22}$ LEFRANC, J. Compreender Schopenhauer, p. 166.
} 
mas prejudica todos, se acaso fores levado a isso"; e há ainda a máxima da maldade, que é “prejudica a todos que puderes”. Segundo Schopenhauer, há três motivações fundamentais de nossas ações: o egoísmo, que tem por fim apenas o próprio bem; a maldade, que só quer o mal alheio; e a compaixão que, ao contrário, só quer o bem do outro. Curioso notar que na filosofia de Schopenhauer o positivo é a dor, enquanto o negativo é o contentamento, o prazer; pois estes não passam de supressão da dor.

Como leitor assíduo dos noticiários tanto locais quanto internacionais, Schopenhauer sempre citava exemplos concretos da perversidade humana, de modo a justificar na prática sua teoria ${ }^{23}$. Nenhum animal irracional é capaz de um ato maligno. Se um animal ataca o outro, é por defesa; se devora o outro, é por fome. Só o homem é capaz de ações malignas apenas pelo desejo de ver a dor do outro; o que dá ao homem um caráter demoníaco $^{24}$. O que poderia justificar, então, este "caráter demoníaco", segundo nosso filósofo, é vivermos uma existência sofrida — o pior dos mundos possíveis; a ilusão de que, causando dor ao outro teríamos a nossa diminuída, como um escape da dor; poderia ser este o motor da maldade. Contudo, o deleite pela desgraça alheia é ainda mais funesto do que um ato provocado por inveja, pois, além de ser demasiadamente humano, o invejoso ainda encontra alguma justificativa para sua ação, enquanto que aquele que faz mal ao outro apenas pela promoção do sofrimento deste é, como foi dito mais acima, demoníaco.

Só uma criatura demasiadamente vil para acreditar que seus sofrimentos são maiores que os do outro. O homem compassivo sempre verá que há dores bem maiores que as suas, de forma que não passará a vida apenas a lamentar sua má sorte. A história dá testemunhos de alguns homens que, mesmo tendo nascido em famílias abastadas, optaram, diante do sofrimento do mundo, por largar tudo, não-querer; atravancando assim a roda da Vontade: Francisco de Assis e Buda, por exemplo: “Quem, mediante tais considerações, torna presente quão necessários para nossa salvação são na maior parte das vezes a necessidade e o sofrimento, reconhecerá que nós outros não deveríamos invejar a sorte, mas

\footnotetext{
23 “Tornou-se conhecido no ano de 1848 que na Inglaterra, não uma vez, mas, em curto espaço de tempo, talvez cem vezes, um cônjuge envenenou o outro, ou ambos em comum os filhos, um após o outro, ou então os levou à morte pela fome e maus tratos, unicamente para obter das sociedades funerárias (burial clubs) os custos do enterro assegurados em caso de morte; para cujo fim haviam registrado uma criança em muitas, até vinte, destas sociedades simultaneamente". Texto extraído do The Times, jornal do qual Schopenhauer era leitor assíduo. Cf. SCHOPENHAUER, A. P/P, p. 196.

${ }^{24}$ SCHOPENHAUER, A. P/P, p. 197.
} 
a desgraça" 25 . Contrariamente ao homem estóico, o compassivo deve se envolver no sofrimento do outro; ele não pode passar pelo mundo como "envolto numa grossa casca pétrea" 26. O parágrafo 172 dos Parerga, mostra um diálogo entre um homem e o espírito do mundo; nele o homem mostra não compreender a existência do sofrimento e do tédio como pagamento para a tarefa da existência, ao que o espírito do mundo responde: "deveria eu lhe dizer que o valor da vida consiste precisamente em que ela the ensina a não querer?! A esta mais alta consagração, a própria vida deve prepará-lo primeiro" ${ }^{27}$. Ao justificar que sua ética possui fundamento, utilidade e objetivo, frente às que lhe antecederam, Schopenhauer diz o seguinte:

em primeiro lugar mostra teoricamente o fundamento metafísico da justiça e do amor humano, e em seguida também aponta o objetivo a que estes, quando realizados com perfeição, devem conduzir. Ao mesmo tempo confessa sinceramente a indignidade do mundo, apontando para a negação da vontade como caminho para sua salvação ${ }^{28}$.

Ora, há filosofia mais cristã?! ${ }^{29}$

\section{Há espaço para compaixão, no pior dos mundos possíveis?}

Há de se perguntar se, no pior dos mundos possíveis, haveria espaço, no coração egoísta do homem, para o nobre sentimento da compaixão: "Entrincheirado em sua subjetividade, separado de todo outro ser humano por um fosso, cada um é para si mesmo seu próprio mundo e dá continuidade a esta guerra de todos contra todos que caracteriza a vida social" 30 . Schopenhauer responde que sim, o homem se constitui de dois móveis: a maldade, que o torna capaz das piores vilezas contra seu próximo; e a bondade, capaz de fazê-lo tomar a dor do outro como fosse sua. Quando tomado pela maldade, o homem se distancia mais ainda dos outros animais, pois só ele é capaz de ações diabólicas; como dissemos antes, os animais irracionais só "agridem" o outro no intuito de se defender ou se

${ }^{25}$ SCHOPENHAUER, A. P/P, p. 233.

${ }^{26}$ SCHOPENHAUER, A. P/P, p. 233.

${ }^{27}$ SCHOPENHAUER, A. P/P, p. 234.

${ }^{28}$ SCHOPENHAUER, A. P/P, p. 229.

${ }^{29}$ Entenda-se que falamos aqui de um cristianismo autêntico, aquele vivenciado pelos santos na renúncia de si mesmos e na vivênciado amor ao próximo - ágape. Não falamos do cristianismo ortodoxo, dogmático, que prioriza a conformidade às leis da Igreja, em detrimento do bem-estar dos homens e dos demais seres.

${ }^{30}$ LEFRANC, J. Compreender Schopenhauer, p. 154. 
alimentar. Portanto, se, assim como é constituído pelo móvel da maldade também é o homem constituído pelo móvel da bondade, ele é capaz de agir moralmente, segundo Lefranc: "O pessimismo do pior dos mundos possíveis não exclui que um homem possa agir por pura bondade, ou seja, que o motivo moral possa algumas vezes contrabalançar a força dos móveis antimorais" ’1. Esses "móveis antimorais" são o egoísmo e a maldade, enquanto que os móveis morais são a bondade, a generosidade, a magnanimidade. Os sentimentos compassivos devem ser estendidos não só aos homens, seres racionais, mas também a tudo o que é vivo e capaz de sentir dor, sofrimento. A ética de Schopenhauer não exclui os animais, as plantas, muito pelo contrário, evidencia que eles também são dignos de nossa compaixão, de nossa piedade; assim se contrapõe às éticas que, considerando a existência de uma alma como elemento distintivo do homem com relação aos outros seres, confere apenas ao primeiro o direito à piedade. O imperativo categórico kantiano, válido apenas para os "seres racionais", está, por conseguinte, em desacordo com a moral schopenhaueriana. Citando um trecho de Sobre o Fundamento da Moral, Lefranc diz: “A piedade ilimitada por todos os seres vivos é a garantia mais sólida para uma conduta moralmente boa, e não necessita de nenhuma casuística" ${ }^{32}$.

Contrariamente à academia, que sempre procurou fundamentar as ações moralmente boas apenas teoricamente, sem se ocupar com o mundo empírico, onde as ações são praticadas, Schopenhauer justifica sua pesquisa não só metafisicamente, mas também empiricamente. Ele também não concorda inteiramente com a fundamentação da moral dada pela teologia, que vê na vontade manifesta de Deus a base para as ações moralmente boas: "A linguagem em que Kant se exprime tem ressonâncias bíblicas, e, para o ateu Schopenhauer, a própria idéia de uma ordem absoluta, ou quer introduzir subrepticiamente a suposição de um ser absoluto capaz de emiti-la ou é infundada"33. Para ele, uma ação moral praticada com base na ameaça de um possível castigo ou na visualização de uma recompensa (a promessa de um céu ou de um inferno, por exemplo), não é uma ação verdadeiramente boa, mas egoísta. A ética de Schopenhauer se distingue da de Kant porque, em vez de pautar-se no "idealmente racional”, nos princípios cognoscíveis a priori, parte das atitudes dos indivíduos, de uma observação empírica. A racionalidade louvada por

\footnotetext{
${ }^{31}$ LEFRANC, J. Compreender Schopenhauer, p. 155.

${ }^{32}$ SCHOPENHAUER, apud LEFRANC, J. Compreender Schopenhauer, p. 156.

${ }^{33}$ JANAWAY, C. Schopenhauer, p. 110.
} 
Kant, não é capaz de tornar alguém uma pessoa boa; pode até mesmo, ao contrário, potencializar seu poder destruidor, ao somar-se a maldade inata ao caráter. Nosso filósofo repudia essa moral da racionalidade, que considera o homem como fim em si mesmo, que confere ao homem uma dignidade tal que, diante dele, o animal irracional não passa de uma "coisa", um meio para se atingir um fim: "Que vergonha essa moral... que não reconhece a essência eterna que existe em toda coisa viva e que se irradia com inescrutável significação a partir de todos os olhos que vêem o sol!"’34.

Schopenhauer critica a ética de seu tempo dizendo que ela "repousa no confortável encosto que Kant ajeitou sob ela: no imperativo categórico da razão prática" ${ }^{35}$. Para ele, a ética de Kant carece de um fundamento sólido. Kant ocupou-se muito com o "dever ser" e se esqueceu de voltar os olhos para a vida humana. É preciso que se deixe de lado as abstrações e que se fundamente uma ética válida também para o homem simples; este fundamento

tem, antes, de ser algo que exija pouca reflexão, ainda menos abstração e combinação, algo que, sendo independente da cultura do intelecto, fale a todo homem, mesmo ao mais tosco, repousando meramente na apreensão intuitiva e impondo-se imediatamente a partir da realidade das coisas ${ }^{36}$.

A moral de Schopenhauer é uma moral sem Deus. Jamais lhe interessou prescrever regras de conduta; para ele, a filosofia é e deve permanecer apenas teórica, especulativa. Ao criticar a moral kantiana, pensa ele: “O que vem a ser uma moral do imperativo categórico, senão na própria forma uma submissão ao mandamento de Deus? Restará, então, um dever cumprido só por dever, o que é contrário a toda experiência moral da humanidade" ${ }^{37}$. Seria o que ele chama de "moral de escravo". Contrariando a moral kantiana, no sentido de não limitar a moral apenas aos seres racionais, eis o pensamento de Schopenhauer, tão bem exposto pelo pesquisador Jean Lefranc:

sabe todo o mundo que vai muita distância de um comportamento racional a um comportamento virtuoso, e que uma ação moralmente admirável pode ser irrefletida e não racional: há muitos exemplos e são irrefutáveis.

\footnotetext{
${ }^{34}$ Janaway citando um trecho de Sobre o Fundamento da Moral. JANAWAY, C. Schopenhauer, pp. $112-113$.

${ }^{35}$ SCHOPENHAUER, A. M/M, pp. 15-16.

${ }^{36}$ SCHOPENHAUER, A. M/M, p.108.

${ }^{37}$ LEFRANC, J. Compreender Schopenhauer, p. 144.
} 
Sabe-o Kant tão bem, que admite que nenhuma ação humana, talvez, tenha sido e nem será jamais cumprida por puro dever $^{38}$.

Mais longe ainda vai Kant, em sua racionalização da moral, ao prescrever o imperativo categórico não só aos homens, mas a todos os seres racionais existentes. Como se houvesse outro ser racional que não o homem; ora, se há, ainda não o conhecemos! Schopenhauer ironiza, dizendo que é provável que Kant estivesse se referindo a "anjinhos", como se neles acreditassem ele e seus leitores. Schopenhauer trabalha com uma razão teórica, que procura dizer como são as coisas, como se dão as ações; e não com uma razão legisladora, que dita regras, que promove uma moral imperativa.

Mais do que uma ciência do como devem agir, a ética tem a ver com o como agem os homens: "o conceito de dever, a forma imperativa da ética só são válidos na moral teológica $[. .$.$] perdem todo o sentido e significação fora dela" { }^{39}$. Só através da investigação, pelo caminho empírico, que podemos verificar se há, em geral, ações de autêntico valor moral, "ações de justiça espontânea, pura caridade e generosidade efetiva" ${ }^{40}$. Reconhecendo qual o impulso que move o homem a ações deste tipo, se pode chegar ao fundamento da ética.

Todos os atos de um homem decorrem do que ele é. No querer ele reafirma sua existência e, dessa existência surgem os atos: “a liberdade está no ser e a necessidade no ato" ${ }^{41}$. Schopenhauer não nega a liberdade, apenas a relaciona à Vontade como ser-em-si. Daí a crítica que Schopenhauer faz de uma "educação moral”, pois o querer, promovido pela Vontade não pode ser mudado; apenas podemos conhecer melhor os motivos que nos levaram a praticar determinada ação, e mesmo tentar mudar as circunstâncias em que surgem os motivos: "Sabemos que não é no formalismo de uma pretensa razão prática que se deve buscar o fundamento da moral, mas no "coração", ${ }^{42}$. Não entenda-se, contudo, que Schopenhauer se negue a formular um princípio da moral, muito pelo contrário: "não prejudiques ninguém, ao contrário, ajuda a todos, quanto puderes", é o princípio formulado por ele e, decerto válido para todos os tipos de moral. Não seria correto classificar esse princípio moral como um imperativo no sentido de que nosso autor não tem por intenção

\footnotetext{
${ }^{38}$ LEFRANC, J. Compreender Schopenhauer, pp. 146-147.

${ }^{39}$ SCHOPENHAUER, A. M/M, p. 119.

${ }^{40}$ SCHOPENHAUER, A. M/M, p.119.

${ }^{41}$ LEFRANC, J. Compreender Schopenhauer, p. 149.

${ }^{42}$ LEFRANC, J. Compreender Schopenhauer, p. 153.
} 
prescrever regras, erigir leis. Tanto que, logo no início do livro IV de $O$ mundo..., ele diz: “Tornar-se prática, conduzir a ação, moldar o caráter: eis aí pretensões antigas que uma intelecção mais perspicaz fará por fim a filosofia abandoná-las" ${ }^{43}$. Além do que, as ações virtuosas podem estar para além da razão: “A virtude é tão pouco ensinada quanto o gênio; sim, para ela o conceito é tão infrutífero quanto para a arte e em ambos os casos deve ser usado apenas como instrumento" ${ }^{44}$.

Na dissertação publicada em 1841, Sobre o fundamento da moral, que tinha por finalidade, ao ser escrita, participar do concurso da Sociedade Real Dinamarquesa de Ciências, cuja questão era: "a fonte e o fundamento da filosofia moral devem ser buscados numa idéia de moralidade contida na consciência imediata e em outras noções fundamentais que dela derivam ou em outro princípio do conhecimento?" ${ }^{45}$, Schopenhauer apresenta a compaixão como o fundamento da moral. Apesar de ser o único concorrente e de ter respondido a uma questão tão discutida entre os filósofos sem que tenham chegado a uma resposta satisfatória, Schopenhauer não teve êxito no concurso. Em concordância com Kant, Schopenhauer afirma que uma ação moral é uma ação sem motivações egoístas. Logo, é moral uma ação motivada por compaixão, que é a fonte e toda bondade; dela procedem virtudes tais como a justiça e a caridade. $O$ homem tomado de compaixão transforma o sofrimento alheio em seu próprio sofrimento. A compaixão é tão própria da consciência humana que independe de conceitos, dogmas, religiões, mitos, cultura, manifestando-se em todos os povos, em várias épocas distintas.

Segundo Lefranc, Schopenhauer apresenta, pois, dois tipos de moral: a da justiça ("não faças mal a ninguém") e a da caridade ("ajuda a todos se o puderes"). Sendo o primeiro tipo negativo, pois trata-se apenas da ausência da injustiça, é nesta segunda forma de moral, que se manifesta com maior nitidez a compaixão:

A negatividade essencial da justiça prepara e possibilita o desdobramento da piedade na virtude de caridade ou de amor à humanidade. Esta última expressão não implica referência alguma à universalidade de uma máxima, mas a um sentimento interior, a uma espontaneidade não reflexa, ou relativamente pouco argumentada. Somente a participação direta de

\footnotetext{
${ }^{43}$ SCHOPENHAUER, A. MVR I, § 53, I 319, p. 353.

${ }^{44}$ SCHOPENHAUER, A. MVR I, § 53, I 320, p. 353.

${ }^{45}$ SCHOPENHAUER, A. M/M, p. 225.
} 
um eu no sofrimento do outro pode superar o egoísmo individual ou coletivo $^{46}$.

\section{A compaixão como negação da vontade}

Eis porque Schopenhauer diz que o fundamento de sua moral é misterioso: de forma não reflexiva, o homem, genuinamente egoísta, é arrebatado pela nobreza da compaixão, pondo-se no lugar do outro que sofre, tomando suas dores. Através da compaixão, negamos à Vontade, voltando ao mistério em que todos, antes divididos, individualizados, voltamos a ser um só e, os papéis se invertem, se confundem: “carrasco e condenado são um só (ser)", diz Lefranc citando $O$ mundo ${ }^{47}$.

Há ainda um terceiro grau da vida ética, além da justiça (grau negativo, sendo a ausência da injustiça) e da caridade: a santidade. Aí a Vontade é realmente suprimida:

a participação no sofrimento do outro só encontra o seu fim na libertação do sofrimento do mundo pela abolição do querer-viver. Além da justiça e da caridade, e dando sentido a toda a vida ética, é a santidade que encontra sua perfeição na renúncia do desejo. Temos portanto 'três morais' ou, dizendo mais exatamente, três graus da vida ética quando se eleva do determinismo dos atos à liberdade do $\operatorname{ser}^{48}$.

Ora, não há como mudar o que se é, não obstante, conhecer o que de fato somos é tarefa difícil, quiçá impossível, pois só nos conhecemos superficialmente; somos como um enigma indecifrável. É no espaço e no tempo, formas puras dos fenômenos, que se dá essa multiplicidade e diferença dos homens. No entanto, na compaixão o indivíduo se reconhece a si próprio no outro, de forma imediata: TAT-TVAM-ASI (expressão sânscrita que quer dizer: "isto és tu”). A compaixão nos faz ver que somos todos uma única e mesma essência, vemos que "há uma unidade cósmica comum a todos, e a agressão ao outro na verdade é um auto-agressão"49. Agir moralmente é, pois, ter a convicção de que, não obstante o "princípio de individuação", apesar de toda a multiplicidade e separabilidade dos indivíduos, há uma unidade deles que é verdadeiramente existente.

\footnotetext{
${ }^{46}$ LEFRANC, J. Compreender Schopenhauer, p. 163.

${ }^{47}$ LEFRANC, J. Compreender Schopenhauer, p. 163.

${ }^{48}$ LEFRANC, J. Compreender Schopenhauer, p. 164.

${ }^{49}$ BARBOZA, J. Schopenhauer: A decifração do enigma do mundo, p.87.
} 
Nosso filósofo não vê como idênticas as ações justas e legais às ações morais. Aqui lembramos novamente Kant, com sua "ação conforme o dever" e "ação por amor ao dever" ${ }^{50}$, ou seja, realmente moral. Honestidade e integridade não são, portanto, frutos de convenções. Como foi dito anteriormente, não se pode chamar de moral uma ação cometida por medo de algum prejuízo, visando alguma recompensa, como honrarias, por exemplo. Dado que Schopenhauer parte da experiência para fundamentar sua teoria, podemos dar vários exemplos de ações praticadas por caridade desinteressada e por justiça espontânea. Vez por outra, os noticiários divulgam casos de pessoas muito pobres que encontraram uma soma muito grande de dinheiro e acabaram indo até à polícia devolver, independentemente de saberem quem era o dono do dinheiro. Mais recentemente, foi divulgado o caso de uma jovem que partiu em defesa de uma criança que estava sendo molestada por um homem em um terreno baldio: antes de pensar em sua própria segurança, mesmo sem conhecer quem era a criança, a jovem foi em sua defesa. Com estes exemplos, vemos como é possível ilustrar as palavras de nosso filósofo: "há pessoas verdadeiramente honestas, como há também trevos de quatro folhas" ${ }^{51}$.

Algumas premissas que podem valer como axiomas para a fundamentação da moral, dizem que egoísmo e valor moral excluem-se um ao outro. Só quando estabeleço uma relação com outros, visando seu bem-estar, é que minha ação é deveras moral; ou, se for o contrário, minha ação visar o mal-estar alheio, apenas o meu próprio proveito, esta ação será condenável moralmente. Portanto, uma ação para ser moralmente válida precisa que seu agente se esqueça de si mesmo, mergulhando no sofrimento do outro e fazendo de tudo para que este se sinta melhor, aliviado: "isto exige que eu me identifique com ele, quer dizer, que aquela diferença total entre mim e o outro, sobre a qual repousa justamente meu egoísmo, seja suprimida pelo menos num certo grau" ${ }^{52}$. Pois bem, esse é o processo da compaixão: esquecendo de mim, tanto a dor quanto a alegria do outro passa a ser a minha dor, a minha alegria. Derruba-se o muro que separa o eu do não-eu - ambos são um só.

$\mathrm{Na}$ filosofia schopenhaueriana, em que a vontade impera majestosa como essência, coisa-em-si, causa de todo o sofrimento existente no mundo, a compaixão aparece como uma via de negação dessa vontade, pois, ao esquecer de mim, mergulhando no outro,

\footnotetext{
${ }^{50}$ Cf. KANT, Immanuel. Fundamentação da Metafísica dos Costumes, primeira seção.

${ }^{51}$ SCHOPENHAUER, A. M/M, p.115.

${ }^{52}$ SCHOPENHAUER, A. M/M, pp. 135-136.
} 
voltamos a ser uma mesma coisa. É preciso que se entenda que sentir compaixão pela dor do outro nada tem a ver com transformar a dor alheia num espetáculo para nosso deleite (“contemplação sádica" da dor alheia); mas é sofrer pondo-se no lugar do outro. Jair Barboza, retomando alguns exemplos dados por Schopenhauer, fala em Jesus Cristo e São Francisco de Assis como pessoas tomadas por esse amor compassivo (ágape) ${ }^{53}$. Para Schopenhauer, portanto, todo amor autêntico é compaixão: “o amor-caridade, o amor-compaixão, ágape, [...] é metafisicamente superior [ao amor-erótico], pois procura evitar o sofrer, neutralizando as dores da existência (como ocorria no caso da contemplação do belo na natureza e nas artes) em vez de perpetuá-los" ${ }^{\text {. }}$. A compaixão é, pois, um sentimento que anula o eu de cada um, eliminando o princípio de individuação, não visando o bem-estar particular, que é mola impulsora do egoísmo. Temos nos santos bons exemplos de ações movidas pela compaixão; ao sentirem que não vale à pena afirmar uma vida tão cheia de sofrimentos, eles a doam ao próximo, para diminuir a dor dos outros. Observando essas palavras, podemos questionar se é válida mesmo a alcunha que se impôs a Schopenhauer de "expoente maior do pessimismo". J. Barboza bem o diz: "na verdade, pelo fundamento de sua ética, ele faz o elogio do amor universal à espécie humana, aos animais, à natureza. A compaixão possibilita a proteção do mundo e de seus habitantes, mediante o amor desinteressado" $" 55$.

Para Schopenhauer, ao mundo cabe não só uma significação física, mas também moral, isto mostra ter ele dedicado parte de seus escritos à abordagem da ética (Aforismos para sabedoria de vida, Sobre o fundamento da moral, o livro IV de $O$ mundo como vontade e representação) e à busca de uma fundamentação da moral, que para ele não é mais que a compaixão. A busca pela compaixão faz desaparecer o ódio e o desprezo que um ser humano possa ter por outro ser. Os seres humanos são genuinamente dotados tanto de pensamentos perniciosos como de pensamentos virtuosos:

O primeiro ponto de discordância das virtudes e dos vícios morais dos homens é aquela oposição das mentalidades fundamentais em relação aos outros, e que adota ou o caráter da inveja ou, o da compaixão. Pois todo homem porta estas duas qualidades diametralmente opostas em seu interior, enquanto provenientes da inevitável comparação do seu próprio estado com o do outro: conforme a atuação do resultado desta sobre seu caráter individual, uma ou outra qualidade se tornará sua mentalidade

\footnotetext{
${ }^{53}$ BARBOZA, J. Schopenhauer: A decifração do enigma do mundo, p. 84.

${ }^{54}$ BARBOZA, J. Schopenhauer: A decifração do enigma do mundo, p. 85.

${ }^{55}$ BARBOZA, J. Schopenhauer: A decifração do enigma do mundo, p. 86.
} 
fundamental e fonte de sua ação. A inveja fortalece o muro entre tu e eu; para a compaixão, este se torna delgado e transparente; ocasionalmente inclusive o derruba, quando então a distinção entre eu e não-eu desaparece ${ }^{56}$.

O ser do homem é definido por suas obras; observando o resultado da soma dos feitos de um homem, ao final de sua vida, podemos dizer quem foi este homem. E é a relação estabelecida entre o homem e seu outro que vai dar conta do grau de compaixão de sua existência. Muito embora, como representações, estejamos submetidos ao princípio de individuação, como objetivação da coisa-em-si que é a vontade, no mundo como vontade, portanto, o princípio de individuação some e passamos a ser um só com os outros.

\section{O mistério da caridade}

A ética schopenhaueriana mostra que a moral se funda na expressão tat tvam asi, ou seja, na compaixão, no reconhecimento de que o homem, o animal, os astros, a folha que cai, são uma só e mesma coisa. A compaixão é, portanto, segundo Schopenhauer, um mistério, visto que vivemos como indivíduos, no mundo como representação. O princípio de individuação ${ }^{57}$, como dissemos antes, gera a ilusão de que nossa vida nada tem a ver com a do outro, ou, com as dos demais seres. A compaixão é um mistério por derrubar o muro existente entre os indivíduos que, em parte e, talvez em sua maior parte, são genuinamente maus. De onde surge esta força que faz ver a dor do outro como minha, é um enigma. "Assim toda caridade totalmente desinteressada constitui uma ação misteriosa, um mistério: por este motivo, a tentativa de justificá-la foi obrigada a se refugiar em muitas ficções" Schopenhauer também dá exemplos de pessoas que agiram movidas por compaixão, como o caso do homem que, certo de que estava prestes a ser fuzilado, se preocupa mais com o bem-estar de seu cão do que com o seu mesmo. A consciência, neste caso, de que a morte não é o fim de tudo, mas apenas do fenômeno e, a visão de que este tudo permanece no que fica, pode justificar uma ação compassiva como essa: "Pois, se assim não fosse, mas tivéssemos a nossos olhos um ser efetivamente frente a seu fim, como poderia este

\footnotetext{
${ }^{56}$ SCHOPENHAUER, A. P/P, p. 190.

${ }^{57}$ Cf. SCHOPENHAUER, A. MVR I, § 23, I 134, p. 171.

${ }^{58}$ SCHOPENHAUER, A. P/P, p. 201.
} 
demonstrar ainda, pelo esforço extremo de suas derradeiras forças, uma participação tão íntima no bem-estar e a sobrevivência de um outro?"59.

Schopenhauer explica que o mistério da compaixão de modo algum surge da reflexão, do meio cultural, econômico, religioso, em que o sujeito esteja inserido. O homem que age de forma compassiva está imbuído deste sentimento de forma inata. Seus atos, mesmo os mais insignificantes dão testemunho de seu caráter:

O que é admirável é como a individualidade de toda pessoa [...] qual tintura penetrante, determina todas as ações e pensamentos da mesma, até a mais insignificante [...] Assim como um botânico conhece a planta inteira por uma folha, e Cuvier construiu o animal inteiro por um osso, é possível a partir de uma ação característica de uma pessoa atingir um conhecimento correto de seu caráter, portanto construí-lo em certa medida a partir daí, inclusive quando esta ação se refere a algo insignificante; então freqüentemente até do melhor modo, pois com coisas importantes as pessoas se cuidam; com insignificâncias seguem, sem grande reflexão, a sua natureza ${ }^{60}$.

Seria, portanto, inútil prescrever regras de conduta com o intuito de modelar o caráter, esperar da razão um guia para as ações. Considerando a não existência do livre-arbítrio, não adianta ao homem querer se propor mudar suas ações, caso tivesse a oportunidade de reviver determinada situação: ele agiria da mesma forma como agiu anteriormente, repetindo o mesmo erro ou acerto. Pois seu caráter, bem como o motivo que determina sua ação, são imutáveis:

o intelecto nada mais tem a fazer durante a ação do que apresentar à vontade os motivos: mas então é obrigado a olhar, como simples espectador e testemunha, como, a partir de seus efeitos sobre o caráter dado, se configura o curso da vida, cuja totalidade de processos se instaura precisamente com a mesma necessidade, como os movimentos de um relógio ${ }^{61}$.

O que faz um homem ter o caráter mais ou menos virtuoso que o outro, também é um mistério; assim como o é o fato de alguém nascer mais ou menos infeliz do que o outro. A isto, Schopenhauer sugere, considerando a existência da justiça, as explicações do

\footnotetext{
${ }^{59}$ SCHOPENHAUER, A. P/P, p. 202.

${ }^{60}$ SCHOPENHAUER, A. P/P, pp. 208-209.

${ }^{61}$ SCHOPENHAUER, A. P/P, p. 211.
} 
misticismo oriental que atribui aos feitos de uma existência anterior os males e as alegrias da vida presente. O futuro, diz o filósofo, é "tão alterável quanto o passado" 62 .

Quanto à negação da Vontade, ela se dá no que se dá a negação do querer-viver. Como submissos que somos à Vontade, que nada mais é do que um querer irrefreável, ao dizermos não a este querer, negamos também a Vontade, provedora de todo sofrimento. Esta negação, segundo Schopenhauer, significa uma passagem para o nada, pois não sabemos o que está para além do não-querer.

A "alegria" pode brotar de uma escolha consciente entre a afirmação da vontade ou a negação da vontade. Se a afirmamos, podemos ser "felizes" através das ilusórias satisfações de nossos desejos; se a negamos, a "felicidade" advêm justamente de não haver mais desejo algum. À negação total da vontade corresponde o ascetismo, no que se nega o próprio corpo, morada da vontade. Negando o corpo e, negando assim a sexualidade, impomos uma barreira à continuidade da vontade, fazemos parar a roda de sansara.

Pela palavra ascetismo refiro-me, propriamente falando, ao aniquilamento refletido do querer que se obtém pela renúncia ao prazer e à busca do desprazer, mediante uma vida de penitência e de expiação, escolhida pessoalmente, para chegar à mortificação incessante da vontade. [...] A própria justiça é o cilício que aplica ao seu portador uma perpétua maceração da carne, e a caridade que priva do necessário é o jejum de todos os instantes ${ }^{63}$.

O intelecto sempre será escravo da vontade enquanto almejar pela felicidade. Um dos maiores e mais difundidos erros da humanidade é o de acreditar que o homem nasceu para ser feliz. Só negando a si mesmo que o fenômeno se liberta da escravidão da vontade.

\section{Referências}

BARBOZA, Jair. Schopenhauer: A decifração do enigma do mundo. — São Paulo: Moderna, 1997.

JANAWAY, Christopher. Schopenhauer. Tradução de Adail Ubirajara Sobral. In: Coleção Mestres do Pensar. São Paulo: Editora Loyola, 2003.

KANT, Immanuel. Fundamentação da metafísica dos costumes. Tradução de Paulo Quintela. In. Col. Os Pensadores. São Paulo: Abril Cultural, 1974.

LEFRANC, Jean. Compreender Schopenhauer. Tradução de Ephraim Ferreira Alves. — Petrópolis, RJ: Vozes, 2005.

${ }^{62}$ SCHOPENHAUER, A. P/P, p. 212.

${ }^{63}$ SCHOPENHAUER, apud LEFRANC, J. Compreender Schopenhauer, p. 169. 
SCHOPENHAUER, Arthur. O mundo como vontade e como representação. Tomo I; tradução, apresentação, notas e índices de Jair Barboza. — São Paulo: Editora UNESP, 2005.

SCHOPENHAUER, Arthur. Parerga e paralipomena. Tradução de Wolfgang Leo Maar. - São Paulo: Abril Cultural, 1980. (Col. Os pensadores)

SCHOPENHAUER, Arthur. Sobre o fundamento da moral. Tradução de Maria Lúcia Mello Oliveira Cacciola. — 2 ed. - São Paulo: Martins Fontes, 2001.

Recebido: $15 / 06 / 11$

Received: 06/15/11

Aprovado: 05/07/11

Approved: 07/05/11 